\title{
INFLUENCE OF CONCENTRATED POWER ENDURACE WORKLOADS ON SPRINTERS' FUNCTIONAL STATE
}

Rita Sadzevičienė, Viktoras Šilinskas, Jonas Poderys

\author{
Lithuanian Academy of Physical Education, Kaunas, Lithuania
}

\begin{abstract}
Research background and hypothesis. There are few studies about the variables of the duration of powerendurance workloads and their total and residual effects.

Research aim was to evaluate the changes in the functional state indices of muscular and cardiovascular systems while two training micro-cycles were designed to develop power-endurance abilities, and the third one was appointed for active rest.

Research methods: Seven sprint athletes performed two micro-cycles of concentrated power-endurance type loads and one micro-cycle was appointed for recovery. Three groups of indices were chosen: muscular power; cardiovascular indices and indices of recovery. 12-leads ECG was registered during the Ruffier test and $30 \mathrm{~s}$ vertical jumping tests.

Research results. Under the influence of two training micro-cycles using concentrated power endurance workloads muscular power deteriorated and the recovery rate was individual. After two training micro-cycles the effect of total fatigue caused an increased biological efforts to perform the locomotion task and cardiovascular changes were more expressed than before training. Seven days was a too short period of time so that the changes in the indices caused by total effect of training would return to the baseline values again.

Discussion and conclusions. Reduced abilities in the regulation of peripheral vascular tone after heavy training could be compensated by the changes in the cardiac function, i. e. by an increase in systolic blood pressure. Cardiovascular indices could be useful for describing changes in the functional state of athletes under the influence of training.
\end{abstract}

Keywords: cardiovascular system, recovery, anaerobic load.

\section{INTRODUCTION}

$\mathrm{T}$ The problem of increasing the efficiency of training has a few important aspects, and the choice of physiologically appropriate means is one of them (Stoboy, 1973; Giada et al., 1998; Price et al., 2000; Trinkūnas et al., 2001). The analysis of the publications of few lasts decades shows new qualitative changes in planning training loads (Giada et al., 1998; Isurinas, Škliaras, 2001; Karoblis, 2001). Various training macro-cycles for solving a particular task are planned. Concentrated power endurance micro-cycles and mezzo-cycles are often planned during the preparatory period and their effect on athlete's performance still remains the interest of sports science. It has been shown that concentrated workloads of endurance and power have a positive effects on the development of capillary density in skeletal muscles, which improves muscular blood flow (Bell eal., 2000; Poderys, 2000). These changes in the cardiovascular system (CVS) are very important as they strongly impact the ability to recover and train using high training workloads (Martienz Caro et al., 1999). There are few studies about variables of the duration of power-endurance workloads, total and residual effects of training on the cardiovascular system. The aim of this study was to evaluate the changes of functional state indices of muscular and cardiovascular systems while two training microcycles were designed to develop power-endurance abilities, and the third was appointed for active rest. 


\section{RESEARCH METHODS}

Seven athletes (age $-22.4 \pm 0.72$ years; body mass $-74 \pm 1.18 \mathrm{~kg}$ ) training in sprint events participated in the research. Their training mezzocycle consisted of three micro-cycles: during two micro-cycles athletes performed concentrated heavy training loads of power-endurance type, and the third micro-cycle was appointed for active rest. The duration of a micro-cycle was 7 days, mezzo-cycle -21 days. Totally 3 assessments were performed: before, at the $15^{\text {th }}$ and at the $22^{\text {nd }}$ days of the mezzo-cycle.

Three groups of indices was chosen for the evaluation of $\mathrm{s}$ in the state of athletes: 1 muscular power indices (triple standing jump); 2 - CVS indices (arterial blood pressure(ABP): systolic (S) and diastolic (D), heart rate (HR), JTinterval and ST-segment depression taken from the electrocardiogram (ECG)); 3 - indices of recovery after testing the workload $\left(_{1 / 2} \mathrm{~T}-\right.$ systolic blood pressure; ${ }_{1 / 2} \mathrm{~T}$ - indicator of blood pressure quality, i. e. (S-D)/S; ${ }_{1 / 2} \mathrm{~T}$ HR; ${ }_{1 / 2} \mathrm{~T}$ JT interval and ${ }_{1 / 2} \mathrm{~T}-$ JT/RR). During the research all participants of the study performed a Ruffier functional test (30 squats per $45 \mathrm{~s}$ ) and the $30 \mathrm{~s}$ vertical jumps test. Twelve standard leads of ECG were registered continuously by computerized ECG analysis system "Kaunas-krūvis".

Statistical analysis was carried out using SPSS 14.0 package for Windows. Standard statistical methods were used to calculate means and standard deviations $( \pm \mathrm{SD})$. A one-way analysis of variance (ANOVA) was used to establish the differences between the measurements. A significance level of 0.05 was used.

\section{RESEARCH RESULTS}

Performed training workloads of power endurance type during first two micro-cycles strongly affected muscular performance indices of athletes. During the first assessment athletes were able to show the result of $7.38 \pm 0.14 \mathrm{~m}$ in triple standing jump. After two micro-cycles all athletes without exception exacerbated their results. On average the result in triple jump decreased by $0.21 \pm 0.04 \mathrm{~m}(\mathrm{p}<0.05)$. The results of the third assessment showed that three athletes $(43 \%$ of cases) improved their result in triple jump, i. e. they jumped more than during initial assessment, two athletes (28.5\% of cases) jumped as much as during the initial study, and the result of two athletes (28.5\% of cases) remained lower than during the first assessment. On average, the results of investigated group in the triple jump during the third assessment did not differ significantly ( $p>$ 0.05 ) from the initial results. The obtained results showed that muscular power indices unambiguously deteriorated because the recovery after training by when using concentrated heavy workloads of power endurance type was individual.

The results of assessment of dynamics of CVS functional indices showed that after two training micro-cycles most of the registered parameters significantly changed. Figure 1 presents the mobilization of CVS while performing exercise tests, i. e. the values of the registered indices

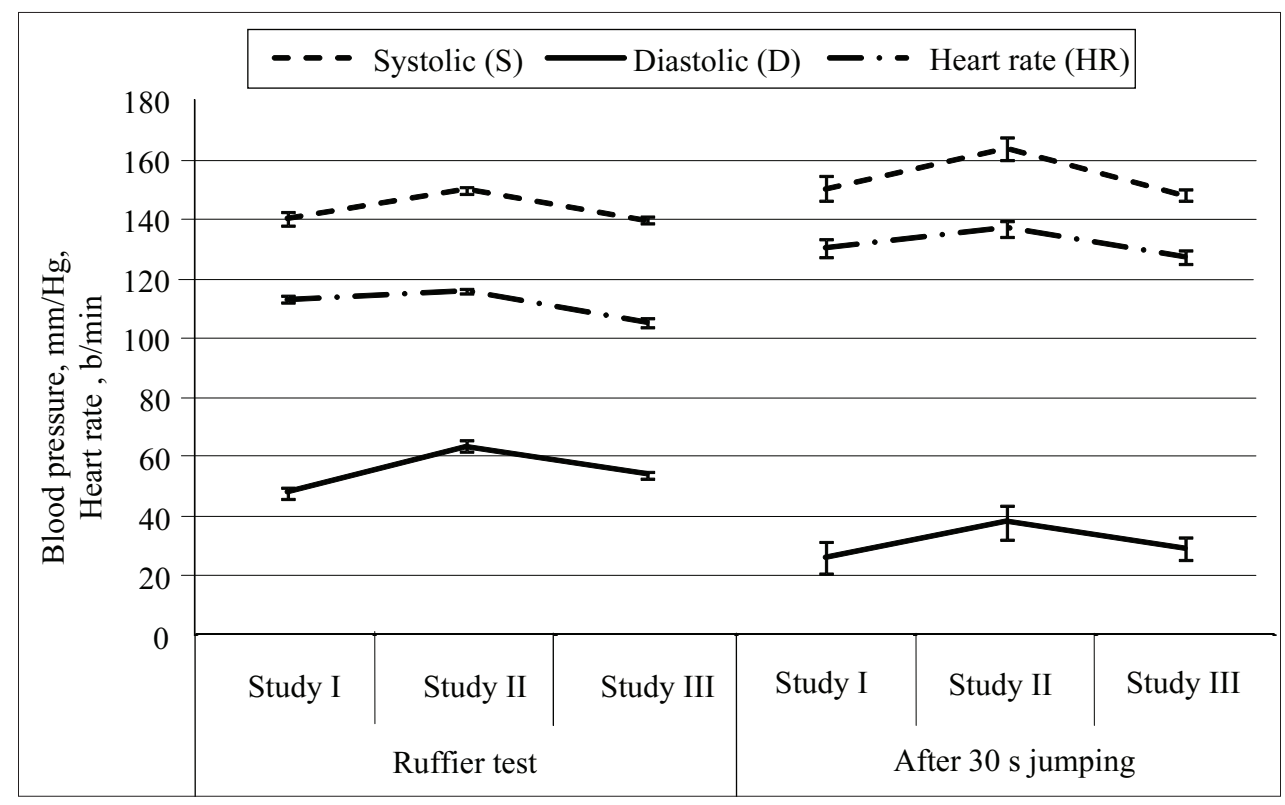

Figure 1. ABP and HR values at the end of modified Ruffier functional test and after $30 \mathrm{~s}$ vertical jumps 
Figure 2. JT-interval, STsegment depression values at the end of modified Ruffier functional test and after $30 \mathrm{~s}$ vertical jumps

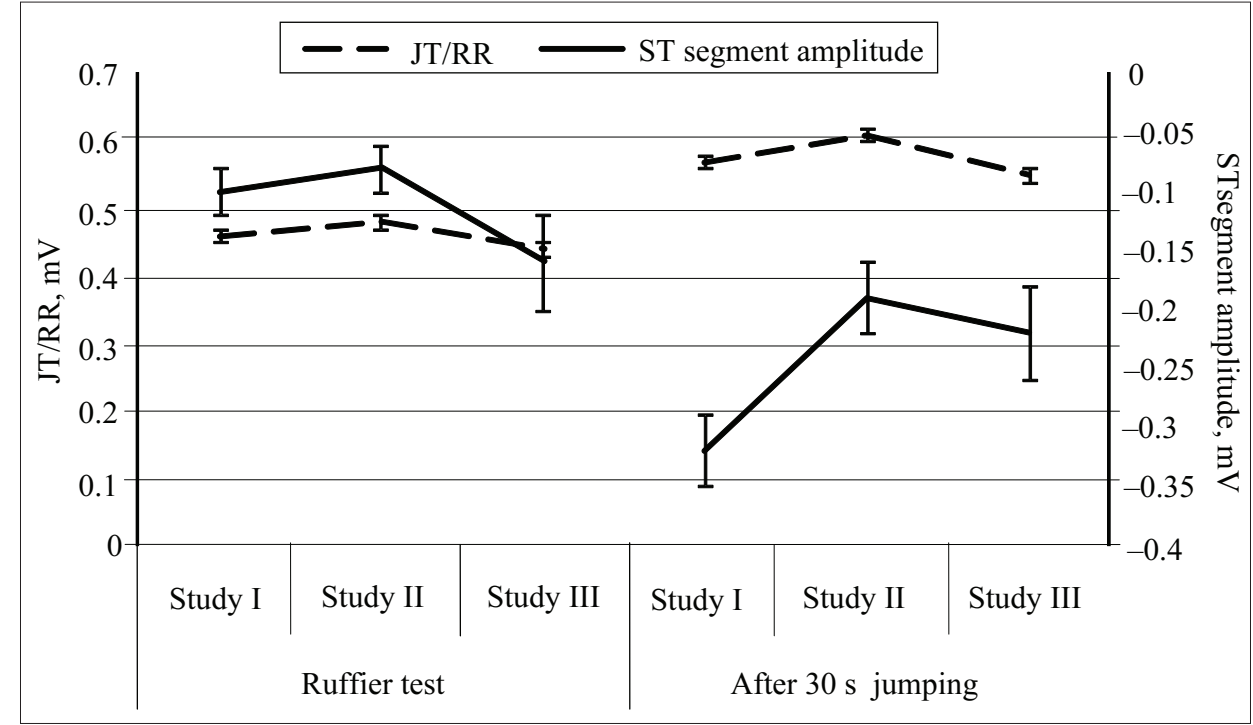

Figure 3. Halves of periods $(1 / 2 T)$ of indicators at the end of modified Roufier functional test and after $30 \mathrm{~s}$ vertical jumps

Note. $*-p<0.05$ compared to study I, ${ }^{* *}-\mathrm{p}<0.05$ compared to study II.

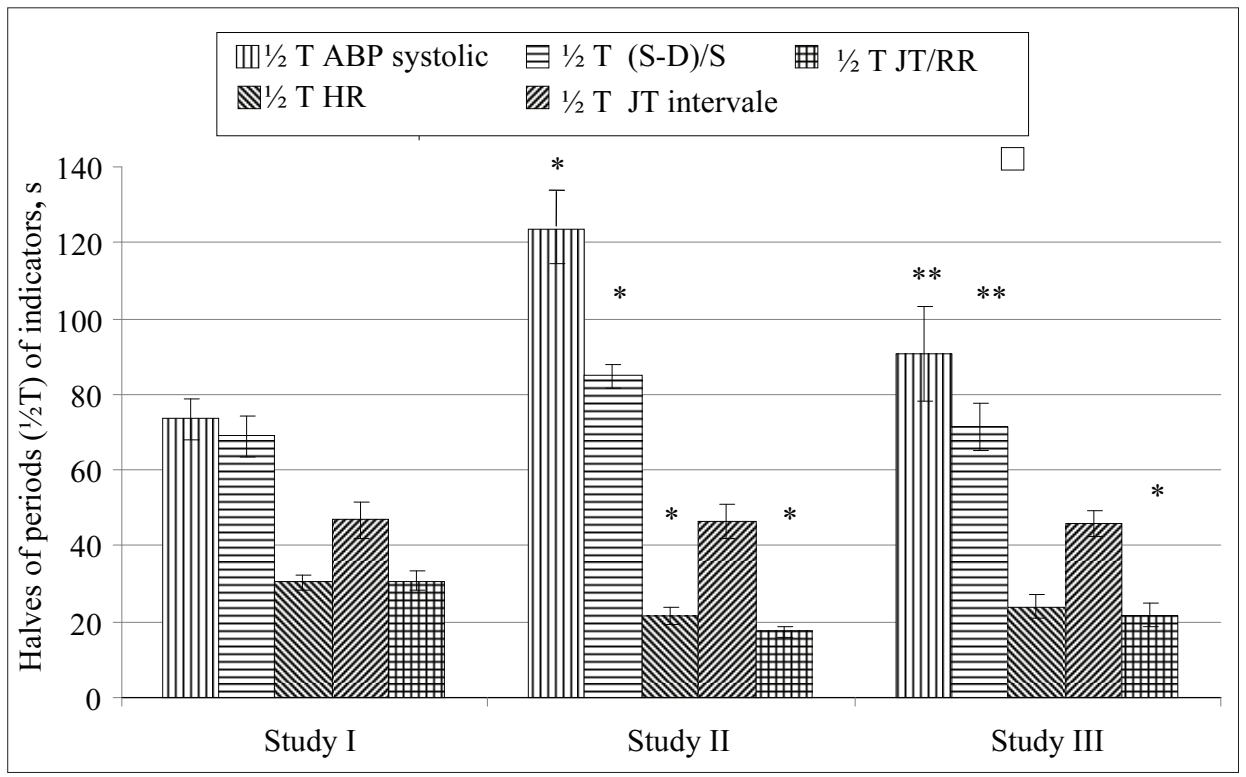

at the end of Ruffier test and after 30 -s vertical jumps. Significant changes $(p<0.05)$ were found in systolic and diastolic ABP responses to both samples of testing workloads, however the pulse pressure of ABP remained unchanged. Analysis of registered ECG indices showed that the change in JT/RR during testing workloads was more expressed after two training micro-cycles than during the first assessment (Figure 2). During the third assessment, i. e. after recovery the changes in JT/RR were close to the same as it was recorded during the first assessment.

Figure 3 presents the data about the speed of recovery of CVS indices $\left({ }_{1 / 2} T\right)$. The results obtained during the study showed that after two training micro-cycles the recovery of the registered ECG indices had statistically significant $(\mathrm{p}<0.05)$ changes. The results of the third assessment showed that one micro-cycle designed for active recovery was not enough for full recovery. The period of time of only 7 days was too short for the dynamics of ECG indices after dosed or maximal exercising to remain slower.

\section{DISCUSSION}

Athlete's body could be described as a complex dynamic system (Korobeynikov et al. 2006), thus changes in the functional state and the interplay of various physiological mechanisms are so important for sports science. All cardiovascular mechanisms are interrelated in supplying oxygen and energy to active tissue. The results in the changes of $\mathrm{ABP}$ at the onset of exercising should be analyzed by taking into account the principle of unity of body functioning. Such changes of ABP can be explained by changes in peripheral vascular tone. It is known that regular physical activity positively 
affects (decreases) both systolic and diastolic ABP not only at rest, but, according to some scientists, alsoduring physical load as well (Keul et al., 1989; Allison et al., 1999; Cornelissen, Fagard, 2005; Chakhunashvili et al., 2011). At first sight similar athletes can responded to the same external physical load with different reactions of CVS. The reactions of systolic blood pressure in response to the same charge can be significantly different. This, of course, determines their different longterm adaptation to the same external physical loads. We have observed recovery of various degree of $\mathrm{ABP}$ indicators during the active rest micro-cycle, and according to average systolic and diastolic blood pressure values of participants of the study, recovery after testing workloads was not the same as it was before training.

Power endurance workloads far less affected the values of HR and JT-interval of ECG. The smaller values in ST-segment depression after two training micro-cycles could be explained as a consequence of the increase in systolic blood pressure.

The change of ratio JT/RR of ECG during the testing provides information about the mobilization of CVS during exercising (Vainoras, Jaruševičius, 1996; Poderys et al., 2005). The results obtained during the study showed that the change of JT/ $\mathrm{RR}$ after two training micro-cycles was more expressed than during the first assessment. This shows that there was more mobilization of CVS in both cases, i. e. while performing a dosed Ruffier test and maximal anaerobic 30 -s vertical jumps test. This could be explained as an effect of total fatigue and increased biological efforts to perform the locomotion task.

The speed of recovery of ECG indices after testing workloads was assessed by halves of periods $(1 / 2 T)$. These halves of periods of recovery could be treated as the index of velocity in metabolic flow of processes (Vainoras, Jaruševičius, 1996). We found that active rest micro-cycle after training was too short so that the changes of indices, caused by total effect of workout, would return to the baseline values again. This means that concentrated powerendurance workloads strongly affect the athlete's body functions and therefore must be scheduled earlier than 3 weeks before competitive activities or applied during preparatory training period. Although high power-endurance loads inhibit strength development (what was confirmed by others and in this our study as well), they stimulate an increase of capillary density in muscles (Bell et al., 2000). It is very important because these longterm adaptational changes are the basis for fast adaptation to heavy training loads and athlete's ability to recover and perform in the next training session.

\section{CONCLUSIONS AND PERSPECTIVES}

1. Under the influence of two training microcycles of concentrated power endurance workloads muscular power deteriorates and recovery rate is individual.

2. Reduced abilities in the regulation of peripheral vascular tone after heavy training could be compensated by changes in the cardiac function, i. e. by an increase of systolic blood pressure.

3. Cardiovascular indices such as halves of periods of recovery $(1 / 2 \mathrm{~T})$ in heart rate, arterial blood pressure, JT interval and in ratio JT/RR could be appropriate indices for describing changes in the functional state of athletes under influence of training.

\section{REFERENCES}

Allison, T. G., Cordeiro, M. A., Miller, T. D. et al. (1999). Prognostic significance of exercise-induced systemic hypertension in healthy subjects. American Journal of Cardiology, 83 (3), 371-375.

Bell, G. J., Syrotuik, D., Martin, T. P., Burnham, R., Quinney, H. A. (2000). Effect of concurrent strength and endurance training on skeletal muscle properties and hormone concentrations in humans. European Journal of Applied Physiology, 81 (5), 418-427.

Chakhunashvili, G., Jobava, N., Guchashvili, M. et al. (2011). Assessment of anthropological, physical and functional indices in sportsmen (basketball players) against the background of high physical loading. Georgian Medical News (Jul-Aug), 196-197, 12-18.

Cornelissen, V. A., Fagard, R. H. (2005). Effects of Endurance Training on Blood Pressure, Blood PressureRegulating Mechanisms, and Cardiovascular Risk Factors. Hypertension, 46, 667-675.

Giada, F., Bertaglia, E., De Piccoli, B. et al. (1998). Cardiovascular adaptations to endurance training and detraining in young and older athletes. International Journal of Cardiology, 65 (2), 149-155.

Isurinas, V., Škliaras, V. (2001). Šiuolaikinis olimpinis rengimas: padetis ir problemos. Sporto mokslas, 2, 8-11. 
Karoblis, P. (2001) Didelio meistriškumo sportininkų rengimo problemos. Sporto mokslas, 2, 2-7.

Keul, J., Lehmann, M., Dickhuth, H. H. (1989). Hypertension, the heart and physical activity. Zeitung Kardiology, 78 (supplement), 199-209.

Korobeynikov, G., Rossokha, G., Koniaeva, L., Medvedchuk, K., Kulinich, I. (2006). Psychophysiological diagnostics of functional states in Sports Medicine. Bratisl Lek Listy, 107 (5), 205-209.

Martienz Caro, D., Rodriguez Garcia, J. A., Munguia, L. (1999). Regulation of cardiac output: An approximation at 3 levels: Organic, cellular, and protein. Revista de Medicina de la Universidad de Nararra, 43 (1), 29-40.

Poderys, J. (2000). Acute and chronic adaptation of cardiovascular system to exercise: Summary of research report presented for habilitation. Kaunas.
Poderys, J., Buliuolis, A., Poderytė, K., Sadzevičienė, R. (2005). Mobilization of cardiovascular function during the constant-load and all-out exercise tests. Medicina (Kaunas). 41 (12), 1048-1053.

Price, D. T., Davidoff, R., Balady, G. J. (2000). Comparison of cardiovascular adaptations to long-term arm and leg exercise in wheelchair athletes versus longdistance runners. American Journal of Cardiology, 85 (8), 996-1001.

Stoboy, H. (1973). Theoretical basis for physical training. Schweiz Z Sportmed, 21 (4), 149-165.

Trinkūnas, E., Poderys J., Grūnovas A. (2001). Greitumo, jëgos ir ištvermès krūvių itaka širdies funkciniam pajègumui. Sporto mokslas, 2, 24-27.

Vainoras, A., Jaruševičius, G. (1996). Veloergometrija/ vykdymo metodai, kompiuterine analize, parametrai, interpretacija. Kaunas.

\title{
FUNKCINĖS BŪKLĖS RODIKLIŲ KAITA TAIKANT JE்GOS IŠTVERMĖS KRŪVIUS
}

\author{
Rita Sadzevičienė, Viktoras Šilinskas, Jonas Poderys \\ Lietuvos kūno kultūros akademija, Kaunas, Lietuva
}

\section{SANTRAUKA}

Tyrimo pagrindimas ir hipoteze. Skirtingos trukmès jègos ištvermès fizinių krūvių suminis ir liekamasis poveikiai širdies ir kraujagyslių sistemai yra mažai nagrinèti.

Tikslas - nustatyti lengvaatlečių raumenų, širdies ir kraujagyslių sistemų funkcinès būklès rodiklių kaitą mezociklo metu, kai sportininkai du mikrociklus atlieka didelius jègos ištvermès krūvius, o trečią skiria aktyviam poilsiui.

Metodika. Funkcinè būklè vertinama pagal tris rodiklių grupes: 1 - raumenų funkcinio pajègumo (trišuolis iš vietos); 2 - ŠKS funkcinès būklès (arterinio kraujo spaudimo rodikliai); 3 - organizmo atsigavimo po fizinio krūvio. Tyrimo metu visi respondentai atlikdavo modifikuotą Rufjè fizinio krūvio ir anaerobinio krūvio mėgini (30 s vertikalūs šuoliai didžiausiomis pastangomis). Dvylika standartinių EKG derivacijų buvo registruojama ir analizuojama kompiuterine EKG analizės sistema „Kaunas-krūvis“.

Rezultatai. Raumenų funkcinio pajègumo rodikliai vienareikšmiškai blogèja tada, kai du mikrociklus sportininkai atlieka didelès apimties jẻgos ištvermès krūvius, o atsigavimo greitis po šių fizinių krūvių yra individualus. Dẻl didelès apimties jègos ištvermès krūvių sumažejusios periferinių kraujagyslių tonuso reguliavimo galimybės yra kompensuojamos centrinio kraujotakos organo širdies funkcija - sistolinio kraujospūdžio padidejjimu. Širdies ir kraujagyslių sistemos funkciniai rodikliai (ŠSD, AKS, elektrokardiogramos JT intervalo ir intervalų JT/RR santykio, atsigavimo pusperiodžiai $(1 / 2 \mathrm{~T})$ po fizinio krūvio mėginio) rodo organizmo funkcinès būklès pokyčius ir teikia informacijos apie suminio bei liekamojo nuovargio požymius.

Aptarimas ir išvados. Raumenų funkcinio pajėgumo rodikliai vienareikšmiškai blogėja tada, kai du mikrociklus sportininkai atlieka jègos ištvermès krūvius, o atsigavimo greitis po šių fizinių krūvių yra individualus. Sumažèjusios periferinių kraujagyslių tonuso reguliavimo galimybės yra kompensuojamos centrinio kraujotakos organo širdies funkcija - sistolinio kraujospūdžio padidejjimu.

Raktažodžai: širdies ir kraujagyslių sistema, atsigavimas, anaerobinis krūvis.

Gauta $2011 \mathrm{~m}$. spalio $25 \mathrm{~d}$.

Received on October 25, 2011

Corresponding author Rita Sadzevičienè

Priimta $2011 \mathrm{~m}$. gruodžio $8 \mathrm{~d}$.

Lithuania Academy of Physical Education

Accepted on December 8, 2011

Sporto str. 6, LT-44221 Kaunas

Lithuania

Tel +370 37302669

E-mailr.sadzeviciene@gmail.com 